Eleonóra L. Zvalená

Univerzita v Novom Sade

Filozofická fakulta

Lektorka slovenského jazyka a literatúry

eleonora.zvalena@ff.uns.ac.rs
UDC: $811.162 .4: 27-236.5$

DOI: 10.19090/ZJIK.2021.101-112 originalni naučni rad

\title{
ŽÁNROVÁ CHARAKTERISTIKA BIBLICKEJ SÁGY V PRIESTORE SLOVENSKEJ LINGVOŠTYLISTIKY
}

ABSTRAKT: Problematika žánrovej charakteristiky biblických textov nebola v slovenskej jazykovede doteraz komplexne spracovaná. V našom príspevku skúmame ságu Starej zmluvy ako žánrovú jednotku, ktorú možno charakterizovat' na základe viacerých kritérií uplatňujúcich sa v komplexnosti a vo vzájomnej podmienenosti. Ságu charakterizujeme ako synchrónny žáner, ktorý má invariantné znaky a vlastnosti vyplývajúce z biblického textu ako špecifického náboženského komunikátu. Zameriame sa na tie vlastnosti biblickej ságy, cez ktoré nadobúda parametre jedinečnosti a odlišnosti vo vzt’ahu k iným biblickým textom. V práci vychádzame $\mathrm{z}$ doterajších teoreticko-metodologických koncepcií slovenskej štylistiky a z jazykovedných sond do problematiky biblických textov.

Klúǔové slová: sága, žáner, štylistika, biblický text, Stará zmluva

\section{ŽÁNER AKO LINGVOŠTYLISTICKÝ POJEM}

Pojem žáner sa pôvodne spájal s oblast'ou literárnej teórie ${ }^{1}$, dnes sa jeho používanie rozšírilo aj na oblast' lingvistiky, hlavne štylistiky, pretože zo žánrového hladiska sa klasifikujú rozličné, nielen umelecké texty. Začína sa preto uvažovat' o jeho modelovej podstate, o jeho vzt’ahu k slohovému postupu a funkčnému jazykovému štýlu. Pri charakteristike žánru ako lingvoštylistického pojmu sa opierame o kategóriu textu, ktorý patrí medzi základné jednotky komunikácie.

J. Mistrík (1985: 273) konštatuje, že „text je jazykovo-tematická štruktúra so zámerným usporiadaním výpovedí, ktorým sa vyjadruje relatívne uzavretý myšlienkový komplex“. J. Findra hodnotí text ako lineárnu jednotku predstavujúcu „funkčnú následnost' (zviazanost') obsahovo-tematických a jazykovo-

\footnotetext{
${ }^{1}$ V literárnej teórii sa žánre členia na lyrické, epické a dramatické. Žáner je označenie pre skupiny literárnych diel, ktoré sa vyznačujú spoločnými kompozičnými, tematickými, jazykovými alebo formálnymi znakmi.
} 
kompozičných zložiek a prvkov“ (2004: 126). Text je teda bilaterálna jednotka majúca obsah a formu - teda hĺbkovú a povrchovú štruktúru. F. Ruščák charakterizuje text ako ,jazykovo-tematický a systémovo-štruktúrne generovaný útvar, obsahujúci všeobecné a jedinečné prvky, ktorý vzniká v konkrétnom časopriestore a situácii a vyjadruje potenciálne uzavretý komplex myšlienok“ (1992: 5). Žáner vnímame ako abstraktnú jednotku, ktorú charakterizujeme na základe kritérií uplatňujúcich sa v komplexnosti a vo vzájomnej podmienenosti. Vychádzame pritom $\mathrm{z}$ teórií, ktoré $\mathrm{v}$ slovenskej štylistike reprezentujú práce J. Findru a D. Slančovej. Teoretickou bázou sú pre nás práce J. Mistríka, F. Ruščáka a J. Mlacka.

D. Slančová definuje žáner ako zovšeobecnenú jednotku, ktorá vzniká „generalizáciou vlastností tematicky, funkčne, kompozične a výrazovo príbuzných komunikátov“ a tiež hovorí, že ,žáner ako abstrakcia sa realizuje konkrétnym komunikátom ${ }^{2}$, útvarom, textom, ktorý sa produkuje a vníma v konkrétnom komunikačnom procese, v konkrétnej komunikačnej situácii““ (Slančová 2001: 44). J. Findra vo svojej monografii Štylistika slovenčiny pokladá žáner ,za priestor, kde dochádza k vzájomnej modifikácii obsahu a formy“ (Findra 2004: 210). Pri klasifikácii vychádza $\mathrm{z}$ formálnych modelových štruktúr (štýl, štýlotvorné činitele) a tiež aj z obsahových modelových štruktúr (slohové postupy). Žáner teda funguje na priesečníku formy a obsahu. Zároveň je podmienený jazykovým, spoločenským, kultúrnym a sociálnym životom konkrétneho spoločenstva, takže žánrové formy majú svoje spoločné, ale aj odlišné znaky. Podla autora je „modelovým priestorom, kde dochádza k vzájomnej modifikácii obsahu a formy a v rámci obojsmernej interferencie aj $\mathrm{k}$ ich vzájomnému spolupôsobeniu pri tvorbe konkrétneho jazykového prejavu“ (Findra 2013: 288). J. Mlackovi sa žáner javí ako „výsledok povrchovej a híbkovej štruktúry“, pričom žáner podl’a neho vzniká aj hybridizáciou medzi štýlmi a postupmi navzájom (Mlacek 2007: 22).

Žáner teda možno komplexne hodnotit' ako zovšeobecnenú kategóriu, ktorá sa prezentuje prostredníctvom témy a jej slohovopostupových realizácií. Za dôležitú pokladáme aj žánrovú konvenciu, t. j. predstavu komunikanta o výslednej podobe konkrétneho žánru (Hoffmanová 1997). Svoju úlohu tu zohráva schopnost' človeka vyberat' intuitívne z podvedomia hotové schémy, ktoré sú ovplyvnené

2 J Mistrík (1985: 370) definuje komunikát ako „obsahovo a formálne uzavretú textovú jednotku“, J. Findra (2004: 130) hovorí, že je to „formálne a obsahovo uzavretá jednotka reči, ktorá vznikla v konkrétnej komunikačnej situácii“‘. Takže každý súvislý komunikát má charakter textu, čiže podobu organizovanej štruktúry. 
komunikačnou normou a kultúrou a tiež zaužívanými sociálnymi pravidlami spoločnosti.

\section{SÁGA AKO ŽÁNER PODL’A LITERÁRNEJ KRITIKY BIBLICKÝCH TEXTOV}

Pojem ságy sa väčšine čitatel’ov literatúry spája so staroseverskou literatúrou. V tom prípade ide o prozaický žáner starej islandskej literatúry z 12 . a 13. storočia. Sága stvárňovala príbehy bojovníkov, Vikingov a iných príslušníkov severských kultúr, takže možno hovorit' o epickom útvare vo forme povesti, eposu alebo hrdinského príbehu. V modernej literatúre termínom sága označujeme rozsiahlu románovú skladbu o osudoch viacerých generácií jednej rodiny. Takou je napríklad kniha anglického spisovatel'a Johna Galsworthyho Sága rodu Forsytovcov. ${ }^{3}$

Avšak aj niektoré texty Biblie sa označujú termínom sága. Tie sa vyskytujú v Starej zmluve. Bibliu tvorí súbor textov, ktoré majú predovšetkým poznávaciu a vzdelávaciu funkciu. Je to literatúra homogénna (tvorí jeden celok s rovnakou funkciou) a heterogénna (obsahuje rozličné typy textov) zároveň. Bibliu tvoria texty, ktoré sú obsahovo i formálne vel'mi rozličné, takže v nej nájdeme naračné, opisné a výkladové texty. Podl’a Fabiana je práve rozprávačstvo „jazykovo-štylistickou podstatou Biblie“(Fabian 1997: 146).

Na skúmanie biblických textov používa biblická exegéza jednu zo svojich pomocných vied - literárnu kritiku. Literárna kritika rozoznáva literárne druhy, literárne žánre, literárnu formu a žánrovú formu. Pre naše potreby si všimneme, ako literárna kritika definuje literárne druhy a literárny žáner. Literárne druhy považuje za útvary, ktoré sa v istom období používajú ako účinné vyjadrovacie prostriedky slovesného umenia (Heriban 1998: 643). Žáner definuje ako kategóriu, ktorá zoskupuje tematicky príbuzné texty s podobnou literárnou formou (Tyrol 1999: 50), pričom pojmom literárna forma označuje formálnu stránku textov.

Podl’a Príručného lexikóna biblických vied je sága ,žáner prozaickej epiky s nevel'kým rozsahom; najčastejšie spracúva historickú tematiku. Historické fakty sa však v ságe či povesti spracúvajú dost' vol’ne. Autor si nekladie za ciel' pravdivo informovat' čitatel'a o histórii. Historické udalosti podriad’uje tendenčným predstavám doby a pritom vytvára pútavý a pre čitatel'a prít’ažlivý dej“ (Heriban 1992: 903). Ságou si izraelský národ oživuje svoju minulost', pripomína si svoj

\footnotetext{
${ }^{3}$ Tieto dva významy slova sága uvádza Slovník slovenského jazyka.
} 
pôvod a svoje začiatky. V pozadí historických faktov je konštantne prítomná spásonosná činnost' Boha $\mathrm{v}$ prospech vyvoleného národa. Mnohé príbehy vysvetl'ujú príčinu a pôvod určitých javov. Z najznámejších príbehov Biblie sa ako sága klasifikuje osud Sodomy a Gomory (kniha Genesis 19).

V pravoslávnom svete sa literárnym žánrom Starého zákona venovalo a venuje niekol'ko biblistov. Najväčší prínos do ich skúmania priniesol v minulosti I. S. Jakimov (1847 - 1885), ktorý pôsobil ako profesor na Sankt-Peterburskej Duchovnej Akadémii. V súčasnosti je to biblista Alexander Cap, profesor Pravoslávnej bohosloveckej fakulty v Prešove. Cap vyčleňuje ságu ako osobitný žáner Starého zákona. Delenie Biblie na žánre odôvodňuje tým, že Bibliu písali l'udia inšpirovaní Duchom Svätým, a tak je ona nielen Božím, ale aj ludským výtvorom, teda literárnym dielom, ktoré môžeme skúmat' ako pamiatku starobylej literatúry. Okrem ságy vyčleňuje ako žánre Starého zákona rodokmene, letopisy, príbehy, mýty, eposy, zvestovania, kroniky panovníkov, rozprávky, hádanky, plače - horekovania, satiru, poéziu, básne, aforizmy, filozofické traktáty, kázne, modlitby, hymny, piesne, pravidlá, závet, pracovno-právne či zákonodarné dokumenty (Cap 2011: 28).

Pri porovnaní prístupu k definovaniu a charakteristike žánru zo strany literárnej kritiky biblických textov a slovenskej štylistiky si možno všimnút, že jeden aj druhý prístup pokladá žáner za abstraktnú jednotku, ktorá vzniká zovšeobecnením vlastností podobných textov. Literárna kritika biblických textov pokladá za rozhodujúci faktor tému, žánre sú teda tematicky príbuzné texty s podobnou formálnou stránkou; štylistika pokladá žáner za fenomén, ktorý vzniká prienikom obsahu a formy, teda je to komplexná jednotka vymedzená témou, funkciou, kompozíciou a jazykovými prostriedkami.

\section{SÁGA V PRIESTORE SLOVENSKEJ ŠTYLISTIKY}

V príspevku sa zameriame na tie vlastnosti biblickej ságy, cez ktoré nadobúda parametre jedinečnosti a odlišnosti vo vzt’ahu k iným biblickým textom. Pri žánrovej charakteristike ságy vychádzame z teoreticko-metodologických koncepcií slovenskej štylistiky, ako aj z doterajších jazykovedných sond do problematiky biblických textov, zároveň prihliadame na východiská teologického charakteru. Pri spracúvaní používame deskriptívnu a explanačnú metódu, ktoré sú založené na postupoch analýzy, syntézy, interpretácie, aplikácie a exemplifikácie.

Pri našom výskume si uvedomujeme, že pracujeme s preloženým (meta)textom. V súvislosti s prekladom biblického textu do slovenčiny 
upozorňujeme na zborník štúdií O prekladoch Biblie do slovenčiny a do iných slovanských jazykov (Dorula 1997), ktorých autori pokladajú preklady Biblie do slovenčiny za texty splńajúce náročné teologické a jazykovo-štylistické kritériá. Biblické texty preložené do slovenčiny sú akceptovatel'né a ich kvalita ich dovoluje žánrovo diagnostikovat', typologicky systemizovat' a komplexne charakterizovat'.

V slovenčine existujú viaceré preklady Biblie, ktoré závisia od pôvodnej prekladanej verzie a od vydavatel’a. V našej štúdii analyzujeme texty Starej zmluvy podl'a vydania Slovenskej evanjelickej cirkvi augsburského vyznania v ČSSR v Spojených biblických spoločnostiach (Londýn) z roku 1979, reedícia $\mathrm{z}$ roku 2015. Budeme pracovat' s textom o Sodome a Gomore, Prvá kniha Mojžišova 19. Zánik Sodomy a Gomory. Zachránenie Lóta. Lótove dcéry.

V našej charakteristike budeme ságu hodnotit' ako osobitnú koncovú modelovú štruktúru. Ságu radíme do systému katechetických náboženských žánrov ${ }^{4}$ a do podsystému biblických žánrov. ${ }^{5}$ Je to nevel'ký písomne realizovaný komunikát zaoberajúci sa historickou tematikou. Sága zobrazuje historické udalosti súvisiace s národom alebo vysvetl'uje príčiny existencie nejakého javu. Ide o jedinečné a neopakovatel'né príbehy zaznamenávajúce významné dejinné udalosti zo života konkrétneho národa, ktoré predznamenali jeho budúcnost' a smerovanie. Tie sú vždy prepojené $\mathrm{s}$ božským riadením osudu a s božskou prozretel'nost'ou. V týchto príbehoch expedient sleduje rozvíjanie udalosti v jej priebehu v čase a priestore od začiatku až po jej ukončenie. Naratívnemu rozmeru ságy zodpovedá jeho hĺbkové podložie, ktoré je vybudované na báze rozprávacieho slohového postupu. ${ }^{6}$ Ten navrstvuje epické motívy, ktoré sú viazané

\footnotetext{
${ }^{4}$ Katechetické žánre vzdelávajú vo veciach viery a náboženstva. Okrem katechetických sú ešte aj konfesijné žánre, ktorými veriaci manifestujú svoju vieru, napr. osobné modlitby a bohoslužby.

5 O náboženskom štýle, jeho vlastnostiach a o jeho rozdelení na jednotlivé žánre písal v roku 1991 J. Mistrík v štúdii Náboženský štýl. Podl'a funkcie a formy delí náboženské žánre na katechetické a konfesijné. Texty Biblie radí ku katechetickým žánrom ako osobitnú skupinu - biblické žánre. Náboženský štýl vyčleňuje ako osobitný funkčný štýl. Za najvýraznejšie znaky tohto štýlu pokladá: hymnickost', emocionálnost', patetickost', úprimnost', intímnost'. Za dôležité štýlotvorné činitele tohto štýlu pokladá: knižnost', rétorickost', dialogickost', uplatňovanie mimojazykových výrazových prostriedkov a rekvizít, predmet náboženských prejavov. Náboženský štýl radí $\mathrm{k}$ subjektívnym heterogénnym štýlom. Napriek vyčleneniu znakov tohto štýlu a jeho charakteristike do svojej monografie Štylistika už autor (Mistrík 1997) tento štýl nezahrnul.

${ }^{6}$ Rozprávací slohový postup je postup, „,v ktorom sa rozvíjajú myšlienky so zretel'om na plynutie javu v čase. Rozprávaním sa sleduje proces“ (Mistrík 1985: 345).
} 
časovou a logickou následnost'ou, ide teda o lineárne rozprávanie, pričom výber obsahovo-tematických segmentov sa podriad'uje čiastkovej téme biblického textu a tiež primárnej téme biblického makrotextu, ktorou je zobrazenie Boha a božskej prozretel’nosti. Princíp chronologickej väzby je základný, aj príčinné súvislosti sa odvíjajú na pozadí časovej následnosti. Naše výklady o takejto slohovopostupovej línii biblickej ságy podporuje aj Fabianova teória o naratívnom rozmeri Biblie (Fabian 1997: 146-153).

Rozprávanie ságy charakterizujú vlastnosti ${ }^{7}$ kohéznosti, sukcesívnosti, explikatívnosti, a do istej miery aktualizovanosti a subjektívnosti. Kohéznost', ktorá vyplýva z časovopostupovej následnosti motívov, sa odohráva sa na osi najprv - potom. Táto vlastnost' sa posilňuje pomocou rôznych druhov konektorov, hlavne lexikálnych a gramatických, napr. Koho tu ešte máš: zat'a, synov, dcéry? Kohokol'vek máš $v$ meste, vyved' ho $z$ tohto miesta, lebo zničíme toto miesto, pretože je naň vel'ká ponosa pred Hospodinom a Hospodin nás poslal zničit' ho. Sukcesívnost' rozprávania ságy je zviazaná s kohéznostou. Chronologická následnost' je posilnená lineárnou následnost'ou, čo vytvára prirodzenú časovopostupovú líniu. Svoju úlohu tu zohráva aj rozprávač a nositelia príbehu (o nich ešte budeme hovorit' $\mathrm{v}$ d’alšej časti nášho príspevku). Vlastnost' explikatívnosti sa uplatňuje zároveň s lineárnou zviazanost'ou motívov a je prvotne podmienená chronologicky, no zároveň sa medzi motívmi uplatňuje príčinný vzt’ah. Text ságy odpovedá na základnú otázku: Čo sa stalo? Prečo sa to stalo? V našom prípade: Sodoma a Gomora boli zničené. Prečo boli zničené? Na základe príčinného vzt’ahu nadväzujú na seba navzájom aj jednotlivé odseky. V ságe preto možno hovorit' aj o výkladovom slohovom postupe ${ }^{8}$, ktorý sa uplatňuje v pasážach objasňujúcich príčinu a následok konania postáv. Taký je napríklad prehovor anjelov k Lótovi: Kohokol'vek máš v meste, vyved' ho z tohto miesta, lebo zničíme toto miesto, pretože je naň privel'ká ponosa pred Hospodinom a Hospodin nás poslal zničit' ho. Opozícia objektívnost' - subjektívnost' nie je

7 Ide o makrokompozičné vlastnosti. V odbornej literatúre (Findra 2013: 194-195) „sa slohové postupy charakterizujú piatimi vlastnost’ami, ktoré sú v binárnej opozícii. Sú to: kohéznost' (súdržnost') - inkohéznost' (nesúdržnost'); explikatívnost' (výkladovost') enumeratívnost' (vypočítavanost'); komutabilnost' (zamenitel'nost') - sukcesívnost' (následnost'); aktualizovanost' - gnómickost' (všeobecnost'); subjektívnost' -objektívnost'. Jednotlivé slohové postupy sa od seba odlišujú nielen tým, že ich charakterizuje istý súbor vlastností, ale aj tým, že tá istá vlastnost', ktorá je príznačná pre dva slohové postupy, sa pri nich neuplatňuje rovnako.“ Najdôležitejšie sú prvé tri vlastnosti.

${ }^{8}$ Výkladový slohový postup si všíma kauzálne vzt’ahy medzi pozorovanými javmi (porov. Mistrík 1985: 356). 
v texte ságy (ani v d’alších biblických textoch) jednoznačná. Na jednej strane sága zaznamenáva historické udalosti, na druhej strane ich zaznamenáva vol'ne, dobovo tendenčne, s ciel'om vytvorit' pútavý dej a čitatel'sky prít'ažlivý príbeh. Podobne je to aj pri opozícii aktualizovanost' - gnómickost'. Sága rozpráva príbeh zaradený do konkrétneho času a priestoru, na druhej strane sú tieto udalosti podávané ako všeobecné pravdy.

Z komplexnej funkcie biblického textu sa do popredia vysúva poznávacia, vzdelávacia a persuazívna funkcia. Expedient rozpráva príbeh a udalosti s ním spojené s ciel'om oboznámit' percipienta s históriou národa (alebo javu) a zároveň podat' svedectvo o Bohu a božskej prozretel'nosti. Jeho zámerom je vyvolat' v čitatel'ovi úctu, bázeň a poslušnost' voči Bohu, získat' ho pre vieru a utvrdit' ho $\mathrm{v}$ nej.

$\mathrm{Na}$ povrchovej úrovni sa sága realizuje cez modelovú štruktúru umeleckých textov. ${ }^{9}$ Túto modelovú štruktúru charakterizujú tieto mimojazykové faktory: písomnost', verejnost', neprítomnost' adresáta, kontaminácia komunikatívnej a umeleckej funkcie.

Základnú slovnú vrstvu tohto žánru tvoria nocionálne a neutrálne slová $\mathrm{z}$ jadra slovnej zásoby, ktoré majú pomenúvaciu funkciu a súvisia $\mathrm{s}$ témou. Ide o substantíva ako muž, syn, dcéra, dom, mesto. Pri upresňovaní výrazu a opise situácie sa využívajú adjektíva, ktoré $\mathrm{v}$ niektorých prípadoch spolu so substantívami vytvárajú združené pomenovania a možno ich zaradit' do mikroparadigmy príznakových štylém, napr. nekvasené chleby; ranná zora, sírový a ohnivý dážd'; solný stíp.

Ked’že sága je naračný text, dôležitú úlohu v ňom plnia plnovýznamové slovesá, ktoré pomenúvajú deje ako nositele výpovede (prišli, sedel, vstal, uchýlili sa, vošli, napiekol, najedli sa, obkolesili, zavrel, nechali, zničil).

Z makroparadigmy štylisticky zafarbených slov tu nájdeme slová z mikroparadigmy biblizmov (Hospodin, anjel, hriech) a knižných slov (ponosa, zahubit', uchýlit' sa, zahynút', počat' diet'a, zachovat' potomstvo) .

$S$ väzbou medzi komunikatívnou a umeleckou funkciou sú späté textové vlastnosti, a to hlavne sémantická mnohoznačnost' výrazu. Početnú skupinu slov tvoria obrazné pomenovania fungujúce na princípe metafory a metonymie. Predstavujú zdroj citovosti a zážitkovosti (Abrahám sa stane vel'kým a mocným národom; aby prikazoval svojim synom a svojmu domu zachovat' po jeho smrti

\footnotetext{
${ }^{9}$ Ako jeden $\mathrm{z}$ funkčných štýlov sa v slovenskej lingvistike vyčleňuje aj umelecký štýl. Podl'a Findru (2013: 276) ,existuje samostatná formálna modelová štruktúra, na základe ktorej autor koncipuje svoj umelecký text".
} 
cestu Hospodinovu; som prach a popol; dcéry, ktoré nepoznali muža; vošli do tône môjho pristrešia; ranili slepotou; aby si nezahynul pre vinu mesta; tvoj služobník našiel priazeň v tvojich očiach; mohla by ma postihnút pohroma; slnko vyšlo nad zemou; sírový a ohnivý dážd' z neba; v krajine nieto muža, ktorý by vošiel k nám; $v$ Okolí jordánskom). V jednom prípade sa v texte o Sodome a Gomore objavuje aj prirovnanie (zo zeme vystupuje dym ako z huty).

Veta ságy je syntakticky pestrá. Nachádzame tu jednoduché vety, tiež súvetia v parataktickom aj hypotaktickom vztahu, častý je príčinný vzt’ah (Vstan̆te, vyjdite z tohto miesta, lebo Hospodin zniči mesto.).

Emocionálnu rovinu textu ságy umocňuje vetná modalita. Silný citový náboj v prehovoroch postáv majú opytovacie a zvolacie vety: Vystríhaj sa toho! Zachrán̆ sa, ide ti o život! Ach nie, Pane!

Kompozičná stavba ságy korešponduje s jej témou, funkciou a s dominanciou rozprávacieho slohového postupu, preto možno jej text rozčlenit' na úvod (príchod anjelov do Lótovho domu), zápletku (obyvatelia mesta chcú sprznit' hostí Lótovho domu), zauzlenie (útok obyvatel'ov mesta na Lótov dom), vyvrcholenie (anjeli zachraňujú Lóta pred útokom l'udí, odchod Lóta, jeho ženy a dcér z mesta pred skazou) a rozuzlenie (zničenie mesta, d'alší osud Lóta a jeho dcér). Toto vnútorné členenie sa odráža aj na vonkajšej výstavbe ságy členením na jednotlivé odseky. Samotný príbeh Sodomy a Gomory je v Knihe Genézis označený

číslicou 19 a nadpisom, dej a smerovanie príbehu sú naznačené a rozčlenené aj pomocou dvoch podnadpisov.

V ságe ako naratívnom žánri sa využívajú nadvetné kontextové jednotky: pásmo rozprávača a pásmo postáv. Rozprávač oboznamuje čitatel’a s udalost’ami, postavami, prostredím. Pásmo postáv je charakterizačným prostriedkom postáv, dáva možnost' účastníkom deja vyjadrit' svoj vzt'ah a svoje city k zobrazovanej skutočnosti. Rozprávač sa vyjadruje nezainteresovane, presne, zrozumitel'ne, zároveň je vo vyjadrovaní stručný a hutný. Zobrazí a opíše iba to najdôležitejšie a najpodstatnejšie pre príbeh. Pri charakteristike postáv využíva nepriamu charakteristiku, napr. Lótova pohostinnost' a úctivost' je opísaná takto: Ked'ich Lót uzrel, vstal a šiel im v ústrety; poklonil sa tvárou k zemi a povedal: Prosím vás, páni moji, uchýlte sa do domu svojho služobníka a prenocujte tam; Celkovo možno konštatovat', že pre rozprávača ságy je príznačná úspornost' výrazu, jeho reč je nocionálna, štylistiky neutrálna, ide teda o objektivizovanú autorskú reč. Reč postáv je sémanticky jasná, syntakticky variabilná (časté sú zložené súvetia), modálne pestrá a má výrazne operatívny charakter. Využíva hlavne rozkazovací 
spôsob, ktorý indikuje konanie postáv a vyžaduje od nich aktívnu reakciu. Napr. Neobzeraj sa a nezastavuj sa vOkoli jordánskom, uteč na pohorie, aby si nezahynul.

Uvádzacie vety priamej reči sú na jej začiatku, sú tvorené slovesami hovorenia a majú neutrálny charakter. Napr. tu si pomyslel, tu riekol, povedal, odpovedal. Čo sa týka slovesnej kategórie času, rozprávač používa minulý čas, prehovory postáv sa realizujú v prítomnom čase.

Ságu Starej zmluvy pokladáme za biblický žáner ovplyvnený dominantnou archetypálnou témou referujúcou o Bohu a božskej prozretel'nosti. Zobrazuje významné udalosti viažuce sa $\mathrm{k}$ dejinám konkrétneho národa alebo k histórii určitého javu. Tento žáner sa konštituoval na priesečníku rozprávacieho slohového postupu a umeleckého štýlu. Na štýle ságy sa podiel'ajú všetky štýlotvorné činitele, za dominantné činitele pokladáme tému a funkciu.

\section{LITERATÚRA}

Biblia. Písmo sväté Starej a Novej zmluvy. 2015. Liptovský Mikuláš: Tranoscius.

Cap, Alexander. 2011. „Literárne žánre Starého Zákona a hebrejská poézia“. Husár, J. ed. In: Pravoslávny biblický zborník III/2011 [elektronický zdroj]: Zborník katedry biblických náuk Pravoslávnej bohosloveckej fakulty Prešovskej univerzity v Prešove. Gorlice: Diecezjalny osrodek kultury prawoslawnej ELPIS w Gorlicach. http://www.okp-elpis.pl/book,open, 1772,0,PRAVOSL\%C3\%81VNY_BIBLICK\%C3\%9D_ZBORN\%C3\% 8DK_III_2011.html (25.08.2021)

Dorul'a, Ján. ed. 1997. O prekladoch Biblie do slovenčiny a do iných slovanských jazykov. Bratislava: Slavistický kabinet SAV.

Fabian, Anton. 1997. „Rozprávačstvo - Jazykovo-štylistická podstata Biblie“. In: Verbum. Časopis pre krest'anskú kultúru, roč. 9, č. 3: 146-153.

Findra, Ján. 2004. Štylistika slovenčiny. Martin: Osveta.

Findra, Ján. 2013. Štylistika súčasnej slovenčiny. Martin: Osveta.

Heriban, Jozef. 1992. Príručný lexikón biblických vied. Rím: Slovenský ústav svätého Cyrila a Metoda.

Hoffmanová, Jana. 1997. Stylistika a... Současná situace stylistiky. Praha: Trizonia 1997.

Mistrík, Jozef. 1991. „Náboženský štýl“. In: Mistrík, J. ed. Studia Academica Slovaca. Prednášky XXVII. letného seminára slovenského jazyka a literatúry. 20. Bratislava, Alfa: 163-175.

Mistrík, Jozef. 1985. Štylistika. Bratislava: Slovenské pedagogické nakladatel'stvo. 
Mistrík, Jozef. 1997. Štylistika. Bratislava: Slovenské pedagogické nakladatel'stvo.

Mlacek, Jozef. 1998. „K štylistike náboženskej komunikačnej sféry a k jazyku súčasnej duchovnej piesne“. In: Mlacek, J. ed. Studia Academica Slovaca. Prednášky XXXIV. letného seminára slovenského jazyka a literatúry. 27. Bratislava, Stimul: 102-117.

Ruščák, Františsek. 1993. „Zvest' o Kristovom narodení ako žáner a text“. In: Ruščák, F. ed. Text a kontext. Zborník z medzinárodnej konferencie v Prešove 18. 19. novembra 1993. Prešov, Pedagogická fakulta Univerzity P. J. Šafárika v Košiciach: 140-144.

Slančová, Dana. 2001. Základy praktickej rétoriky. Prešov: Náuka.

Slovník slovenského jazyka. Online. Dostupné na internete <https: //slovnik.aktuality.sk/pravopis/slovnik-sj/?q=s\%C3\%A1ga > (15.08. 2021)

Tyrol, Anton. 1999. Poznámky k štúdiu biblickej exegézy. Svit: Katolícke biblické dielo. 
Eleonóra L. Zvalená

\section{GENRE CHARACTERISTICS OF THE BIBLICAL SAGA IN THE AREA OF SLOVAK LINGUISTIC STYLISTICS}

\section{Summary}

In our paper, we characterized the biblical saga as a synchronous genre unit based on the criteria applied in Slovak Stylistics. We leaned on the existing theoretical and methodological concepts of Stylistics, especially the concept of J. Findra, which perceives the genre at the intersection of content model structure (stylistic procedure) and formal model structure (functional style, stylistic creating factors) and also the concept of D. Slančová, who demarcates the genre on the basis of thematic, functional, compositional, formal and linguistic criteria. The saga is a small written text in its range, that depicts events in history of a particular nation or explains the reasons for the existence of a certain phenomenon. Like all biblical communicates, the saga is influenced by a dominant reference in the form of an archetypal theme referring to God. The saga is built at the intersection of narrative stylistic procedure and artistic style. We consider the most important function of this text to be cognitive, educational and persuasive. The language of the saga is characterized by its simplicity, comprehensibility, modesty in expression, and figurative names. The syntax of the saga is diverse, with the presence of simple sentences and the compound ones. The dominant narrative dimension of the saga corresponds to its composition, which applies superscript contextual units for the segmentation and gradation of the text, mainly the narrator's section and the character's section. The narrator's discourse can be evaluated as an objectified author's discourse, the section of characters is a means of characterization, which is defined by the emotionality of the expression, that is manifested mainly by a varied sentence modality. We consider the theme (which is represented by narration) and function to be the dominant stylistic creating factor of the saga. It should be recalled that an important role in the formation of individual biblical genres (and thus also sagas) is played by the connection with the respective civilization, $i$. e. taking into account the historical, social, cultural and religious aspects that influenced their final form.

Key words: saga, genre, stylistics, biblical text, Old Testament 
Eleonora L. Zvalena

\title{
ŽANROVSKE KARAKTERISTIKE BIBLIJSKE SAGE U PROSTORU SLOVAČKE LINGVOSTILISTIKE
}

\begin{abstract}
Rezime
U našem radu smo biblijsku sagu okarakterisali kao sinhronu žanrovsku jedinicu na osnovu kriterija koji se koriste u slovačkoj stilistici. Oslanjali smo se na dosadašnje teorijsko-metodološke koncepcije stilistike, pre svega na koncepciju J. Findre, koji žanr poima kroz presek sadržajne modelske strukture (književna tehnika) i formalne modelske strukture (funkcionalni stil, stilski činioci), kao i na koncepciju D. Slančove, koja žanr izdvaja na osnovu tematskih, funkcionalnih, kompozicionih, formalnih i jezičkih kriterijuma. Saga je po obimu manji pismeno realizovani tekst koji predstavlja istorijske događaje vezane za istoriju konkretnog naroda i objašnjava uzroke egzistencije neke pojave. Kao i na ostale biblijske tekstove, i na sagu utiče dominantna referenca u obliku arhetipske teme koja referiše o Bogu. Saga se gradi na preseku govornog stilskog postupka i umetničkog stila. Smatramo da su saznajna, obrazovna i persuazivna funkcija najvažnije funkcije ovog teksta. Jezik sage odlikuje jednostavnost, razumljivost, ekonomičnost izraza, a prisutna su i prenesena značenja. Sintaksa sage je raznovrsna, javljaju se tu jednostavne, ali i složene rečenice. Dominantnoj narativnoj dimenziji sage odgovara njena kompozicija, koja koristi iznadrečenične kategorije za raščlanjavanje i hijerarhizaciju teksta, uglavnom delove teksta pripovedača i delove teksta likova. Govor pripovedača se može vrednovati kao objektivizovani autorski govor; delovi teksta likova predstavljaju sredstvo karakterizacije likova za koji je tipična emocionalnost izraza i ispoljava se pretežno šarolikim rečeničnim modalitetom. Za izražajno dominantnu osobenost sage smatramo temu (koja se uobličava naracijom) i funkciju. Treba napomenuti da nezanemarljivu ulogu prilikom formiranja pojedinih biblijskih žanrova (a to znači i sage) igra povezanost sa određenom civilizacijom uzimajući u obzir istorijske, socijalne, kulturne i religijske aspekte koji su uticali na njihov konačan oblik.
\end{abstract}

Ključne reči: saga, žanr, stilistika, biblijski tekst, Stari zavet 